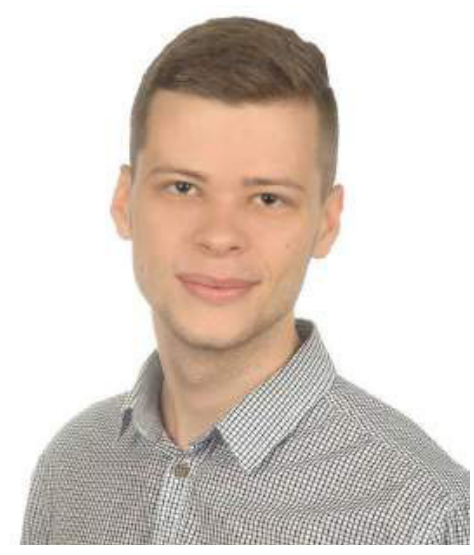

Тарас Паска,

аспірант,

ДВНЗ «Прикарпатський національний

університет імені Василя Стефаника»

(м. Івано-Франківськ)

Taras Paska,

Postgraduate Student,

Vasyl Stefanyk Precarpathian National University

(Ivano-Frankivsk)

aksap55@gmail.com

ID orcid.org/0000-0002-4579-388X

Удк 004.5:376.68 (477.86)

ББК 74.2

\title{
ВПЛИВ СУЧАСНОГО ІНФОРМАЦИЙНОГО СЕРЕДОВИЩА НА ФОРМУВАННЯ ОСОБИСТОСТІ ДІТЕЙ ТРУДОВИХ МІГРАНТІВ ГІРСЬКИХ ШКІЛ ПРИКАРПАТТЯ
}

\section{INFLUENCE OF THE MODERN INFORMATION ENVIRONMENT ON PERSONALITY FORMATION OF CHILDREN OF LABOR MIGRANTS OF PRECARPATHIAN MOUNTAIN SCHOOLS}

У статті проаналізовано проблеми, пов'язані із становищем дітей трудових мігрантів-«євросиріт» у гірському регіоні Івано-Франківщини (Прикарпаття). Розкрито механізм стимуляції соціальної активності «євросиріт» за допомогою нових форм комунікації в сучасному суспільстві (Інтернет, соціальні мережі, Skype, Viber, sms-зв'язок, мобільний зв'язок, електронна пошта та ін.) Особлива увага звернено на роль сучасних інформаційно-комунікаційних технологій у збереженні родинних зв'язків. Висвітлено вплив сучасних медіа на особистісний розвиток дітей трудових мігрантів, структуру їх дозвілля, позитивні і негативні наслідки взаємодії з комп'ютерними технологіями.

Висновки статті ґрунтуються на результатах власного дослідження (анкетування дітей середнього та старшого шкільного віку), проведеного у гірських школах Надвірнянського району Івано-Франківської області. Дослідження продемонструвало достатній рівень обізнаності дітей трудових мігрантів з можливостями використання сучасних комунікаційних технологій для отримання необхідної інформації та спілкування. Нові засоби комунікації допомагають дітям вирішувати свої особистісні проблеми, більш впевнено почувати себе в суспільстві, підтримувати регулярне спілкування з родиною.

Ключові слова: євросироти, діти трудових мігрантів, інформаційно-комунікаційні технології, комп'ютерна залежність, соціальні мережі.

The problems connected with the children's environment of labor migrants - «euroorpgans» in the mountain regions of Ivano-Frankivsk (Precarpatia) during the last years are highlighted and analyzed. The attempt is made to substantiate the social-pedagogical principles of family education in the distant families of Ukrainian migrant workers. The mechanism of stimulation of the social activity of euroorpgans with the help of new communication forms in the modern society is revealed. A special attention is paid to the role of modern informatic-communication technologies in the maintaining of family relationships. The influence of modern medias on the children's personal development of labor migrants, as well as the structure of their leisure, the positive and negative consequences of interaction with computer technologies is highlighted.

The conclusions of the article is based on the results of my own research- the questionnairing of school children is held in the mountain schools of Nadvirna region of Ivano-Frankivsk oblast. Researches have demonstrated a sufficient level of awareness of children of migrant workers with possibilities to use informatic-communication technologies in order to get new information and communication. New means of communication help children to solve their personal problems, feel themselves more confident in the society, encourage regular communication with the family.

Keywords: euroorpgans, children of labor workers, informative-communicative technologies, computer addiction, social networks.

В статье анализируются проблемы, связанные с положением детей трудовых мигрантов-«евросирот» в горном регионе Ивано-Франковщины (Прикарпатье). Раскрыт механизм стимуляции социальной активности «евросирот» с помощью новых форм коммуникации в современном обществе (Интернет, социальные сети, Skype, Viber, sms-связь, мобильная связь, электронная почта и др.) Особое внимание обращается на роль современных информационнокоммуникационных технологий в сохранении родственных связей. Раскрыто влияние современных медиа на личностное развитие детей трудовых мигрантов, структуру их досуга, положительные и отрицательные последствия взаимодействия с компьютерными технологиями. 
Выводы статьи основываются на результатах собственного исследования (анкетирования детей среднего и старшего школьного возраста), проведенного в горных школах Надворнянского района Ивано-Франковской области. Исследование показало достаточный уровень осведомленности детей трудовых мигрантов с возможностями использования современных коммуникационных технологий для получения необходимой информации и общения. Новые средства коммуникации помогают детям решать свои личностные проблемы, более уверенно чувствовать себя в обществе, поддерживать регулярное общение с семьей.

Ключевые слова: евросироты, дети трудовых мигрантов, информационно-коммуникационные технологии, компьютерная зависимость, социальные сети.

Постановка проблеми в загальному вигляді та її зв'язок з важливими науковими та практичними завданнями. Проблема трудової міграції існує в Україні декілька останніх десятиліть. За цей час країну змушені були покинути з метою працевлаштування, за різними оцінками, від 7 до 10 мільйонів громадян, переважно сімейних. Особливо великий відтік робочих рук спостерігається у гірських районах Українських Карпат, соціально-економічний розвиток яких залишається на низькому рівні. За висновками дослідників, часто трудова міграція негативно відбивається на соціальному здоров'ї родини, приводить до руйнування сімейних відносин.

Досить довгий час проблема виховання і соціалізації дітей трудових мігрантів (так званих євросиріт), не вважалася актуальною і суспільство не звертало увагу на їх становище та соціально-психологічне здоров'я. Адже діти на емоційному рівні важко переживають розрив з рідним соціумом. Тривала розлука з батьками може створювати сприятливе підґрунтя для формування й проявів девіантних елементів у поведінці школяра.

Однак швидкий розвиток нових форм комунікації в сучасному суспільстві (новітні медіа) та поява своєрідного віртуального інформаційного середовища суттєво вплинули на становище дітей трудових мігрантів. Розповсюдження персональних комп'ютерів і бурхливий розвиток глобальних комп'ютерних комунікацій протягом останнього десятиріччя висуває нові вимоги до роботи з цією категорією дітей.

Активна робота з інформаційно-комунікаційними технологіями (IKT) формує в дітей більш високий рівень навичок і вмінь - самостійно здобувати знання, користуватись різноманітними джерелами інформації, спонукає до творчої та пошукової діяльності, підвищує інформаційну культуру.

Сучасне інформаційне середовище формує у школярів-євросиріт здатність гнучко адаптуватися в мінливих життєвих ситуаціях, самостійно критично мислити, бути комунікабельними в різних соціальних групах, самостійно працювати над розвитком власної моральності, інтелекту, культурного рівня. Родині і педагогам потрібно докласти максимум зусиль, щоб завдяки ІКТ діти трудових мігрантів відчули особисту потребу в розвитку своєї когнітивної сфери, а в майбутньому і в професійному розвитку.

Аналіз останніх досліджень і публікацій, у яких започатковано розв'язання проблеми. Окремі теоретичні аспекти соціально-педагогічної діяльності з дітьми трудових мігрантів досліджували у своїх працях українські (В. Андрєєва, О. Безпалько, Н. Гевчук, С. Золотухіна, Т. Комісарової, К. Левченко, Є. Лозинська, О. Маланцева, Ф. Мустаєва, Я. Раєвська, Д. Пенішкевич, В. Пігіда, В. Сподар, І. Трубавіна, В. Хлюпіна, К. Шевченко, В. Шульга) та зарубіжні (К. Гвовяк, Д. Гізіцька, Е. Завіаша-Маслак, Б. Кенджерська, А. Мруз, С. Козак, Ю. Станьчик, С. Труш, 3. Шарота) вчені.

Разом з тим, на наш погляд, варто активізувати наукові дослідження про вплив інформаційно-комунікаційних технологій на формування особистості дітей трудових мігрантів - учнів гірських шкіл Прикарпаття.

Формування мети статті. Мета статті - проаналізувати соціально-педагогічні проблеми дітей трудових мігрантів гірських шкіл Прикарпаття; з'ясувати вплив сучасного інформаційного середовища на формування особистості дітей-євросиріт; розкрити механізми стимуляції соціальної активності дітей прикарпатських заробітчан за допомогою нових форм комунікації в сучасному соціумі.

Виклад основного матеріалу дослідження з повним обґрунтуванням отриманих наукових результатів. Українське заробітчанство за кордоном асоціюється переважно із західними областями. Прикарпаття вважають одним із регіонів, який постачає найбільше трудових мігрантів до Італії, Португалії, Бельгії, Польщі, Чехії та інших європейських країн. Низькі зарплати, відсутність роботи, бажання допомогти родині - усе це спонукає їхати на чужину в пошуках гідного рівня життя все нових і нових мешканців краю.

На сьогодні в нашій країні відсутня єдина вичерпна система збору даних про трудову міграцію в Україні. Натомість, статистичні дані збирають різні установи, зокрема державні органи, міжурядові та неурядові організації. Дані про трудову міграцію, отримані на рівні країни, часто суперечливі й істотно відрізняються в різних джерелах. Крім того, виникають розбіжності через застосування таких понять, як короткостроковий, довгостроковий трудовий мігрант або емігрант.

За даними Міжнародної організації з міграції (МОМ), отриманими в рамках проекту «Дослідження та діалог щодо політики у сфері міграції і грошових переказів в Україні», українська довгострокова трудова міграція (тривалістю більше одного року) характеризується зростанням з 2006 року по даний час. Упродовж $2014-$ 2015 рр. офіційний обсяг міжнародної трудової міграції з України було оцінено в 688 тисяч осіб (424 тисячі довгострокових і 264 тисячі короткострокових трудових мігрантів). Чисельність внутрішніх трудових мігрантів в Україні перевищує 1,6 млн. осіб і сягає 9\% економічно активного населення [5].

Постійно зростає чисельність українців, які проживають на території Європейського Союзу. у 2015 р. їх налічувалося 905, 2 тисячі чоловік (понад 6\% іноземців з третіх країн на території ЄС).

За даними Євростату в 2015 р. півмільйона українців отримали посвідку на проживання в ЄС, з них $75 \%$ з метою працевлаштування. Крім того, у Росії перебуває на заробітках біля трьох мільйонів українців [2]. 
Результати опитування, проведеного фахівцями МОМ у 2014-2015 рр., показали, що під час першого виїзду з країни середній вік українського довгострокового трудового мігранта становив 34-39 років. Зрозуміло, що такий віковий профіль мають переважно батьки, на утриманні яких знаходяться діти дошкільного та шкільного віку. Так, згідно з даними обстеження українських трудових мігрантів, які працюють в Італії, тільки 6,1\% жінок не мають дітей, тоді як понад s залишили вдома 1-2 дитини, а майже 8\% - трьох і більше дітей [6, с. 25].

Сьогодні категорію дітей, чиї батьки тривалий час перебувають на заробітках за кордоном, прийнято вважати дітьми трудових мігрантів, або ж «євросиротами».

Сім'ї, в яких принаймні один з батьків є трудовим мігрантом, дослідники визначають як «дистантні». у таких сім'ях виховання і соціалізація дітей може бути неповноцінною, особливо коли на заробітках перебуває мати (а саме фемінізація трудової міграції є характерною ознакою українського заробітчанства) чи обоє батьків. Сім'я як соціальний інститут зазнає деформації і перестає повною мірою виконувати свої функції.

Розлука з батьками завжди є для дитини стресом незалежно від ї̈ віку, статі, рис характеру. Діти на емоційному рівні важко переживають розрив з рідним соціумом. Це суттєво впливає на стан соціальнопсихологічного здоров'я євросиріт, адже сім'я виступає для них основним джерелом емоційної та матеріальної підтримки і психологічного захисту. Тривала розлука з батьками може створювати сприятливе підґрунтя для формування й проявів девіантних елементів у поведінці дитини.

Досвід соціально-педагогічної роботи з дітьми трудових мігрантів шкільного віку свідчить про необхідність систематичної профілактики негативного впливу на їхню поведінку. Зокрема, нерідко спостерігається зниження успішності в навчанні; потрапляння під вплив проблемних компаній; труднощі в побудові міжособистісних стосунків з родичами та однолітками; вживання наркотиків, алкоголю; скоєння правопорушень; розвиток хронічних захворювань унаслідок послаблення контролю за здоров'ям дитини; емоційні розлади, відчуття непотрібності й незахищеності від зовнішнього світу; поширення споживацьких настроїв, небажання вчитися чи працювати i, нарешті, формування сталого бажання виїхати з країни. Спеціалісти висловлюють також побоювання, що позбавлені особистого досвіду сімейного проживання євросироти можуть мати проблеми при створенні власної сім'ї, негативні наслідки чого повною мірою виявляться вже в недалекому майбутньому [4, с. 16].

На це вказують останні дослідження українських та зарубіжних науковців, які вивчають окремі аспекти соціальнопедагогічної роботи з дітьми трудових мігрантів та вплив ІКТ на їхню соціальну активність і родинні зв'язки.

Однак із швидким розвитком нових форм комунікації в сучасному суспільстві та появою нового інформаційного середовища становище дітей-євросиріт суттєво змінилося.

Сучасне покоління молоді живе в епоху, яка отримала назву «ера новітніх інформаційних технологій та прогресу» [1, с. 147]. Інтернет, соціальні мережі, комп'ютерні технології, засоби мобільного та відеозв'язку, телебачення стали невід'ємними атрибутами світу нинішнього молодого покоління. Вони стали необхідністю для кожної дитини, виявом докорінно нового інформаційного середовища, в якому живуть і розвиваються діти. Технологічний прогрес дозволяє кожній молодій людині повсякчас залишатися «на зв'язку».

Сучасні інформаційно-комунікаційні технології перетворилися на могутній соціальний інститут, що виховує громадянські, національні, духовні почуття, звички, спонукання, мотиви, наміри і т. п. Наприкінці другого десятиліття XXI ст. новітні медіа, Інтернет, реклама швидко збільшують чисельність своєї аудиторії, залучають до своїх спільнот все більше учасників і є більш впливовими, ніж традиційні періодичні видання, телебачення і радіо.

У наш час, як стверджує А. Сухорукова, деякі ЗМІ та соціальні мережі володіють майже безмежним радіусом дій, величезними можливостями культурно-інформаційної експансії. Вони нав'язують свої культурні та споживацькі стандарти, смаки [3, с. 23].

Інформаційне середовище перетворилось на особливий повноцінний паралельний світ, який, як і реальний світ, взаємодіє з особистістю дитини. За допомогою екрана телевізора, планшета, ноутбука, смартфона чи айфона діти мають можливість пізнавати безмежний всесвіт, що їх оточує. Раннє залучення школярів, а нерідко і дошкільників, до віртуального світу, за висновками психологів, стосується когнітивного, соціального, емоційного, сенсорного, духовного та інших аспектів їхнього особистісного розвитку.

Особливе занепокоєння викликають факти спрямованого негативного впливу сучасних IKT на молоде покоління. Адже у їхній практиці часто використовуються методи підсвідомого впливу. Особливо вразливими в такій ситуації є діти-євросироти, які позбавлені батьківської уваги і живуть в кардинально змінених умовах. Замість дорослого посередником-медіатором між ними і навколишнім світом часто стає комп'ютер або телевізор, а середовище роздвоюється на те, що дійсно оточує (часто занадто вузьке) і те, що існує в комп'ютері - без кордонів і обмежень, поза часом і простором, бо час і простір у віртуальному світі можна змінювати.

Діти із дистантних сімей часто не готові до адекватного сприймання інформації, яка вимагає глибокого аналізу і критики. У той же час емоційний вплив на вразливу дитячу душу настільки великий, що залишається в пам'яті назавжди. Тому важливим завданням нашого дослідження стало виявлення характеру впливу сучасного інформаційного середовища, нових форм комунікації на життя і активність дітей трудових мігрантів, на їх особистісний та психофізичний розвиток.

3 цією метою нами було розроблено спільно з науковцями Інституту наук про виховання Краківського педагогічного університету ім. Комісії Народної Освіти анкету-опитувальник «Як я використовую сучасні способи комунікації?». Протягом 2016 року проанкетовано 156 дітей-євросиріт середнього і старшого шкільного віку, які навчаються у школах гірського регіону Івано-Франківщини (Надвірнянська ЗОШ І-ІІІ ст. №3, Надвірнянська ЗОШ I-III ст. №4, Саджавська ЗОШ І-ІІІ ст. Надвірнянської районної ради, Ланчинська ЗОШ І-ІІІ ст. Надвірнянської районної ради). Із загальної кількості опитаних дітей у 14\% на момент анкетування за кордоном перебували мама 
і тато, а в решти 86\% був відсутній хтось один із батьків. Термін відсутності у сім'ї одного або двох батьків - від трьох місяців до двох років.

Новітні засоби спілкування останніми роками має змогу використовувати все більша кількість дітей заробітчан. Так, для спілкування з батьками, які перебувають за кордоном, опитані школярі найбільше використовують мобільний телефон (85\%). Крім того, набирає популярності спілкування по Skype та Viber (33\%). Не користується популярністю такі засоби, як SMS (3\%) та електронна пошта (3\%).

Майже всі школярі в сучасних умовах масового розповсюдження всесвітньої мережі Інтернет мають змогу ним користуватися в домашніх умовах. Однак інтенсивність використання Інтернету з різними соціальними групами є неоднаковою. Найбільша група опитаних використовує Інтернет для спілкування 3 друзями (86\%), значно менша кількість для спілкування із знайомими (39\%) та контактів з батьками (33\%). Майже не практикується спілкування засобами Інтернету із вчителями (лише 6\%), із бабусями-дідусями (через відсутність комп'ютерних навичок у людей старшого віку) - 3\% та із незнайомими людьми (з міркувань безпеки) - $2 \%$.

Анкетування дало змогу виявити, на які сфери діяльності поширюється використання Інтернету. Так, опитані школярі в однаковій мірі користуються всесвітньою мережею для навчання (60\%) і зв'язку (60\%), дещо більше для розваг (62\%). Окрім того, 21\% учасників анкетування здійснюють за допомогою Інтернету покупки.

Актуальною в сучасному інформаційному середовищі є проблема самостійного пошуку необхідної інформації з метою отримання нових знань. З'ясувалося, що найбільш популярним джерелом інформації для учнів $€$ пошукові системи мережі Інтернет (95\%). Другим за важливістю джерелом поповнення знань для євросиріт $€$ їхні батьки (56\%). Наступними за значенням засобами отримання інформації учасники анкетування назвали книги (20\%) та соціальні мережі, зокрема Facebook, Instagram (17\%), а найменш популярними виявилися газети (3\%) та телебачення $(1,5 \%)$.

Про важливе місце нових форм комунікації свідчить і те, що кількість опитаних дітей, які читають книги в електронній формі перевищує на 3\% кількість тих, які читають книги в текстовій (традиційній) формі. 42\% учасників анкетування віддають перевагу дистанційним формам самоосвіти для здобуття нових вмінь і навичок за допомогою Інтернету (електронні курси і вебінари), порівняно із традиційними. Сучасні школярі показали достатній рівень засвоєння таких інтерактивних елементів, як вміння використовувати програмне забезпечення: електронні підручники і посібники, програми-тренажери, електронні словники, довідники, енциклопедії, відеоуроки, тестові системи для контролю знань, тематичні комп'ютерні ігри.

Актуальною проблемою сьогодення є тривалість щоденної роботи за комп'ютером та перебування в мережі Інтернет. 28\% дітей відводять для такої діяльності кожного дня менше 1/5 вільного часу. 55\% учасників анкетування відповіли, що вони приблизно половину вільного часу щодня проводять в Інтернеті. Решта $17 \%$ дітей перебувають в мережі більше 4/5 вільного часу. Це, переважно діти старшого шкільного віку з ознаками комп'ютерної залежності, яка призводить до різкого скорочення всіх інших видів діяльності та обмеження спілкування з іншими людьми.

Сучасні дослідження свідчать, що частина дітей трудових мігрантів змушена шукати собі друзів за інтересами або з подібними життєвими проблемами у віртуальному світі, щоб самоствердитися і абстрагуватися від психологічних проблем у реальному світі. Тому важливо звертати увагу на формування у дітей-євросиріт навичок свідомого користувача Інтернету. Важливо вберегти школярів від небезпечних сайтів та аккаунтів у всесвітній мережі, зокрема від «груп смерті», що стали популярними сьогодні серед підлітків та юнацтва в країнах Східної Європи («Синій кит», «Море китів», «Тихий Дім», «Розбуди мене в 4.20», «Рожеві феї», «f 57» і т. п.).

Медики і психологи серед негативних наслідків комп'ютеризації для психічного і фізичного здоров'я молоді звертають увагу на ряд психіччних хвороб, які можуть розвинутися на фоні надмірного використання IKT, таких як номофобія, кіберхвороба, Facebook-депресія, ігрова залежність, кіберхондрія та ін.

Сучасні IKT дають змогу дітям трудових мігрантів, за відсутності батьків, оперативно отримувати інформацію щодо збереження власного здоров'я та способів лікування. 28\% опитаних уже вміє користуватися такими ресурсами, як сайти медичних установ, медичних блогерів, сайти аптек, реабілітаційних та діагностичних центрів, тренажерних залів, сайти медичних навчальних закладів. Однак поки що можливості Інтернету та соціальних мереж в цьому плані використовуються недостатньо.

Під час дослідження особливостей особистісного розвитку школярів в умовах сучасного інформаційного середовища ми звернули увагу на проблему використання ними свого вільного часу. Аналіз відповідей показав, що більшість опитаних віддають перевагу безпосередньому спілкуванню з друзями під час дозвілля (81\%). Наступні позиції у даному рейтингу займають такі форми дозвілля, як заняття з комп'ютером (телефоном, ноутбуком, планшетом) - 48\%, безпосереднє спілкування в колі сім'ї - 46\%, заняття спортом - 32\%. Найменш популярними формами проведення вільного часу стали для опитаних читання книг (12\%), та відвідування театру/кіно (5\%).

3'ясовано, яким чином відбувається спілкування дітей трудових мігрантів із друзями та знайомими. Найбільш популярними є зустрічі під час прогулянки (77\%). На другому місці зафіксовано спілкування в соціальних мережах - 48\%, на третьому місці - зустрічі в кафе (28\%). Наступні позиції займають: відвідування будинків культури (18\%), спільні сеанси комп'ютерних ігор - 14\%, спілкування по Skyре - 11\%, заняття спортом на стадіонах та у спортивних залах - 6\%.

Крім того, було проведено діагностику референтного кола осіб і референтних груп опитаних євросиріт, оскільки вони відіграють важливу роль у становленні особистості дитини. У зв'язку з цим, значний інтерес для нас мало питання про те, як часто діти трудових мігрантів проводять з родиною свій вільний час. Причому, під поняттям «родина» малися на увазі один чи двоє батьків, або дідусь і бабуся, або брати і сестри. Більшість опитаних (58\%) проводить завжди або часто свій вільний час з родиною (завжди - 15\%, часто - 43\%). 
Відчувають дефіцит спілкування з родиною 42\% дітей. Вони або спілкуються рідко з найближчими людьми (39\%), або взагалі ніколи не спілкуються з родиною (3\%). Це, перш за все пояснюється тривалою відсутністю одного або обох батьків, які перебувають за кордоном на заробітках.

Серед пріоритетних форм спілкування євросиріт зі своєю сім'єю переважна більшість дітей віддала перевагу безпосередньому спілкуванню з членами родини (67\%). Однак сучасні ІКТ також займають вагоме місце серед засобів комунікації з родиною. Так, бажаними засобами спілкування названо Skype (29\%), мобільний телефон (28\%). Значно менше діти спілкуються з родиною через соціальні мережі (5\%).

Можна зробити висновок про те, що з розвитком сучасних IКT діти трудових мігрантів отримали досить зручні форми комунікації з батьками, які тривалий час відсутні в своїх сім'ях. Однак для дітей як молодшого, так і старшого шкільного віку безпосередній емоційний контакт з найближчими родичами є незамінною і необхідною умовою повноцінного психічного особистісного розвитку.

Ключова проблема, яку було з'ясовано під час анкетування - це проблема довіри євросиріт, які проживають в умовах дистантної сім'ї. Найбільший рівень довіри опитані школярі проявили до батьків (68\%). На другій позиції знаходяться друзі (21\%). Решта 11\% дітей найбільше довіряє своїм родичам. Ніхто з учасників анкетування не виявив довіри до друзів у соціальних мережах. Це, зокрема, свідчить про своєрідний «психологічний імунітет» опитаних школярів до маніпулятивних впливів у соціальних мережах, вміння адекватно сприймати інформацію сучасних медіа та здатність до критичного мислення.

Отже, діагностика рівня довіри євросиріт показала, що для переважної більшості обстежених школярів гірських шкіл родинні цінності мають пріоритетне значення. Ці діти комфортно почувають себе у спілкуванні з батьками та родичами, а психологічну атмосферу в таких сім'ях можна вважати сприятливою для формування їхньої особистості, повноцінного і всебічного розвитку.

Висновки і перспективи подальших досліджень. Наше дослідження доводить, що сучасне інформаційне середовище значною мірою змінює соціальні відносини дітей-євросиріт. Перш за все, новітні засоби комунікації допомагають дітям краще засвоювати соціальний досвід, розширювати соціальні зв'язки, збільшувати коло спілкування. Адже саме у міжособистісних соціальних відносинах вони мають можливість найбільш яскраво проявити себе як особистість.

Важливим чинником повноцінного розвитку дітей трудових мігрантів гірських шкіл Прикарпаття є можливість систематичного спілкування з батьками, іншими родичами завдяки сучасним ІКТ. У даний час діти не відчувають особливих труднощів для підтримання родинних зв'язків у періоди тривалої відсутності рідних. І це вигідно відрізняє їх від того покоління євросиріт, дитинство яких припало на період 10-20-річної давнини, коли основним засобом спілкування було традиційне листування.

Наше дослідження підтвердило високий рівень обізнаності дітей трудових мігрантів із можливостями використання Інтернету, соціальних мереж, засобів телефонного та відеозв'язку для отримання необхідної інформації та спілкування, організації дозвілля, самоосвіти та саморозвитку.

Проблема впливу сучасного інформаційного середовища на формування особистості дітей трудових мігрантів потребує подальшого дослідження. Зокрема, актуальними питаннями можна вважати дослідження ролі новітніх способів комунікації в адаптації членів сім'ї до тривалої розлуки, у здійсненні профілактики сімейних конфліктів, стабілізації та корекції внутрішньосімейних відносин, допомоги в організації спілкування на відстані.

1. Kędzierska B., Mróz A. Komplementarny wymiar edukacji w społeczeństwie globalnej informacji / Barbara Kędzierska, Anna Mróz. - OlsztynBiałystok: Centrum Badań Społecznych UWM Katedra UNESCO UWM, 2017. - S. 143-158

2. Євростат: статистика трудової міграції [Електронний ресурс]. - Режим доступу: ukranews.com/ua/news/474604

3. Інформаційний бюлетень кафедри соціальної педагогіки та соціальної роботи. Випуск 4, тематичний: Теоретичні, методичні і практичні проблеми соціальної педагогіки та соціальної роботи : тези доповідей I Всеукраїнської науково-практичної конференції, 26 травня 2016 р. - Івано-Франківськ : HAIP, 2016. - 251 с.

4. Малиновська О. Трудова міграція населення: соціальні наслідки та шляхи вирішення / О. Малиновська - Київ: НІСД, 2011. - 40 с.

5. Міграція як чинник розвитку в Україні. Збірник Міжнародної організації з міграції (МОМ). Представництво в Україні [Електронний ресурс]. - Режим доступу: iom.org.ua/sites/default/files/mom

6. Проблеми дітей трудових мігрантів: аналіз ситуації. Міжнародний жіночий правозахисний центр «Ла Страда - Україна» / за заг. ред. К. Левченко - К., 2006. - 64 с.

\section{Reference}

1. Kędzierska B., Mróz A. Komplementarny wymiar edukacji w społeczeństwie globalnej informacji / Barbara Kędzierska, Anna Mróz. - OlsztynBiałystok: Centrum Badań Społecznych UWM Katedra UNESCO UWM, 2017. - S. 143-158

2. Yevrostat: statystyka trudovoyi mihratsiyi [Elektronnyy resurs]. - Rezhym dostupu: ukranews.com/ua/news/474604

3. Informatsiynyy byuleten kafedry sotsialnoyi pedahohiky ta sotsialnoyi roboty. Vypusk 4, tematychnyy: Teoretychni, metodychni i praktychni problemy sotsialnoyi pedahohiky ta sotsialnoyi roboty: tezy dopovidey I Vseukrayinskoyi naukovo-praktychnoyi konferentsiyi, 26 travnya 2016 r. - Ivano-Frankivsk : NAIR, 2016. - 251 s.

4. Malynovska O. Trudova mihratsiya naselennya: sotsialni naslidky ta shlyakhy vyrishennya / O. Malynovs'ka - Kyyiv: NISD, $2011 .-40$ s.

5. Mihratsiya yak chynnyk rozvytku v Ukrayini. Zbirnyk Mizhnarodnoyi orhanizatsiyi z mihratsiyi (MOM). Predstavnytstvo v Ukrayini [Elektronnyy resurs]. - Rezhym dostupu: iom.org.ua/sites/default/files/mom

6. Problemy ditey trudovykh mihrantiv: analiz sytuatsiyi. Mizhnarodnyy zhinochyy pravozakhysnyy tsentr «La Strada - Ukrayina» / za zah. red. K. Levchenko - K., 2006. - 64 s.

Рецензент: Джус О.В., кандидат педагогічних наук, доцент, ДВНЗ «Прикарпатський національний університет імені Василя Стефаника» 